\title{
Diagenesis along Fractures in an Eolian Sandstone, Gale Crater, Mars
}

D. W. Ming, A. S. Yen, E. B. Rampe, J. P. Grotzinger, D. F. Blake, T. F. Bristow, S. J. Chipera, R. Downs, R. V. Morris, S. M. Morrison, D. T. Vaniman, R. Gellert, B. Sutter, A. H. Treiman, and the MSL Science Team

The Mars Science Laboratory rover Curiosity has been exploring sedimentary deposits in Gale crater since August 2012. The rover has traversed up section through $\sim 100 \mathrm{~m}$ of sedimentary rocks deposited in fluvial, deltaic, lacustrine, and eolian environments (Bradbury group and overlying Mount Sharp group). The Stimson formation lies unconformable over a lacustrine mudstone at the base of the Mount Sharp group and has been interpreted to be a cross-bedded sandstone of lithified eolian dunes. Mineralogy of the unaltered Stimson sandstone consists of plagioclase feldspar, pyroxenes, and magnetite with minor abundances of hematite, and Ca-sulfates (anhydrite, bassanite). Unaltered sandstone has a composition similar to the average Mars crustal composition. Alteration "halos" occur adjacent to fractures in the Stimson. Fluids passing through these fractures have altered the chemistry and mineralogy of the sandstone. Silicon and S enrichments and depletions in $\mathrm{Al}, \mathrm{Fe}, \mathrm{Mg}, \mathrm{Na}, \mathrm{K}, \mathrm{Ni}$ and $\mathrm{Mn}$ suggest aqueous alteration in an open hydrologic system. Mineralogy of the altered Stimson is dominated by Ca-sulfates, Si-rich X-ray amorphous materials along with plagioclase feldspar, magnetite, and pyroxenes, but less abundant in the altered compared to the unaltered Stimson sandstone and lower pyroxene/plagioclase feldspar. The mineralogy and geochemistry of the altered sandstone suggest a complicated history with several (many?) episodes of aqueous alteration under a variety of environmental conditions (e.g., acidic, alkaline). 